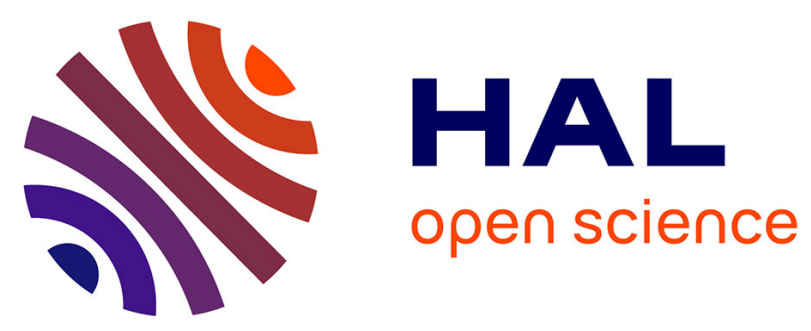

\title{
Are absolute and comparative judgements about road traffic-risks inherent in speeding realistic? A study among French traffic regulation offenders
}

Cécile Martha, Patricia Delhomme

\section{- To cite this version:}

Cécile Martha, Patricia Delhomme. Are absolute and comparative judgements about road trafficrisks inherent in speeding realistic? A study among French traffic regulation offenders. Transportation Research Part F: Traffic Psychology and Behaviour, 2014, 26, Part A, pp.126-137. 10.1016/j.trf.2014.06.013 . hal-01649562

\section{HAL Id: hal-01649562 \\ https://hal-amu.archives-ouvertes.fr/hal-01649562}

Submitted on 27 Nov 2017

HAL is a multi-disciplinary open access archive for the deposit and dissemination of scientific research documents, whether they are published or not. The documents may come from teaching and research institutions in France or abroad, or from public or private research centers.
L'archive ouverte pluridisciplinaire HAL, est destinée au dépôt et à la diffusion de documents scientifiques de niveau recherche, publiés ou non, émanant des établissements d'enseignement et de recherche français ou étrangers, des laboratoires publics ou privés. 
Running head: RISK JUDGEMENTS AND SPEEDING

Are absolute and comparative judgements about road traffic-risks inherent in speeding realistic? A study among French traffic regulation offenders

Cécile Martha ${ }^{(1)}$, Patricia Delhomme ${ }^{(2)}$

(1) Aix-Marseille Université, CNRS, ISM UMR 7287, 13288 Marseille Cedex 09, France.

E-mail: cecile.martha@univ-amu.fr

${ }^{(2)}$ IFSTTAR, Département AME (Aménagement Mobilité Environnement), Laboratoire de Psychologie des Comportements et des mobilités, 25 allée des Marronniers, CS 90508, 78008 Versailles Cedex, France.

E-mail: patricia.delhomme@ifsttar.fr

Correspondence address:

Cécile Martha

Aix-Marseille Université, CNRS, UMR 7287, Institut des Sciences du Mouvement, Faculté des Sciences du Sport, 163 avenue de Luminy, CP 910, 13288 Marseille cedex 9, France.

Phone number: +33-4 911704 39; Fax: +33-4 91170412

E-mail: cecile.martha@univ-amu.fr 


\begin{abstract}
A few studies have shown that road users can express realistic risk judgements, in the sense that they perceive higher risk when their behavior is in fact riskier. Our aim was to examine whether the realism of absolute and comparative judgements about speeding risks could be found among an at-risk driver population made of 539 French traffic regulation offenders taking a driving licence points recovery course.

The results showed that course takers' absolute judgements regarding speeding-ticket risk were realistic: the more course-takers had the intention to drive fast and reported drivingrelated sensation-seeking (DRSS), the more they evaluated themselves as being at risk of having a speeding-ticket. The realism was also observed when considering comparative judgements regarding speeding-ticket risk, but only among the more than 25 years old participants. Moreover, the realism was not observed when considering course takers' absolute and comparative judgements regarding speeding-induced crash risk. Hence, it is important to increase communication about the dangerousness of speeding among specific groups such as traffic regulation offenders, above all among young course takers who reported high speeds and DRSS.
\end{abstract}

Key words: Absolute judgements; Comparative optimism; Realistic judgements; Selfreported speeding; Driving-related sensation-seeking. 
Are absolute and comparative judgements about road traffic-risks inherent in speeding realistic? A study among French traffic regulation offenders

\section{Introduction}

Despite the continuous decrease of the number of fatalities due to road traffic crashes in France, in 2011 the National Interministerial Observatory for Road Safety (ONISR, 2012) reported 3963 road fatalities and 81251 injured road users. In France as in other occidental countries, drivers' involvement in risky driving behaviour such as speeding, as well as violations of traffic rules and laws, are major contributing factor to a higher rate of crashes and injuries (Campbell \& Stradling, 2003; Parker, Manstead, \& Stradling, 1995; West et al., 1993). High-speed driving is invariably the most frequent violation (Nallet, Bernard, \& Chiron, 2010). More than 10740000 sanctions for speeding have been administered in 2011 in France (ONISR, 2012). Hence, from a fight against road insecurity perspective, identifying and understanding the psychological factors associated with involvement in risky driving behaviour such as speeding constitutes a critical objective. The present study focuses on the role of risk judgements, that means one's subjective evaluation of the likelihood of experiencing a negative outcome such as a crash. More particularly, it focuses on the realism (Delhomme \& Meyer, 1999; Rutter, Quine, et Albery, 1998; Shepperd, William, Klein, et al., 2013) of risk judgements by investigating to what extent one can evaluate his/her personal risk of two different outcomes, risk of crash and risk of sanctions, as being higher when his/her behaviour is in fact riskier.

Individuals' risk judgements can be investigated from both an absolute and comparative perspective (see Causse, Delhomme, et Kouabenan, 2005, and Ranby et al., 2010, for a review). The former allows measuring how an individual judges his or her own risk without 
comparison to a reference group. The latter consists in investigating risk judgements from a social comparison perspective. In this vein, in the field of road-traffic safety, numerous studies have shown that drivers (Chaurand \& Delhomme, 2013; Delhomme, 1991; 2001; Delhomme, Verlhiac, \& Martha, 2009; Machin \& Sankey, 2008), cyclists (Chaurand \& Delhomme, 2013; Martha \& Delhomme, 2009) motorcyclists (Rutter et al., 1998), and even pedestrians (Castanier, Paran, \& Delhomme, 2012) exhibit comparative optimism, i.e., tend to believe that their driving abilities are better, or their vulnerability to road crashes lower, than those of others. Several terms such as unrealistic optimism (Weinstein, 1980), optimistic bias (Weinstein \& Klein, 1996), or comparative optimism (Weinstein \& Klein, 1996) have been used in the literature to describe this phenomenon (Radcliffe \& Klein, 2002; Shepperd, Carroll, Grace, et al., 2002). In the present study, we preferred to use the term comparative optimism to describe the belief that one's risk is below average without regard to whether this belief is correct. It was only when we took into account more objective criterion such as selfreported speeding that we qualified as realistic or unrealistic both absolute risk judgements and comparative risk judgements, whether the latter revealed comparative optimism, similarity judgments (when people see their own risks as similar to those of others) or comparative pessimism (when people see their risks as higher than those of others).

Comparative optimism appears both pervasive and persistent (Shepperd, Helweg-Larsen \& Ortega, 2003). It may originate from several motivational causes (Shepperd et al., 2002) such as the self-enhancement bias, the desire to deny vulnerability to harm, and the need for control that may lead to an exaggerated belief in personal control (McKenna, 1993). On the opposite, prior experience with an event diminishes comparative optimism (Harris, 2007; Weinstein, 1987). Several cognitive mechanisms also underlie comparative optimism (Shepperd et al., 2002), such as the tendency to transform interpersonal distance into risk differences (Harris, Middleton \& Joiner, 2000), as well as the representativeness heuristic that 
can lead people to select or create a high-risk target for comparison. For example, being asked to judge the likelihood that the average person will experience a car accident may prompt people to think not of a typical driver, but instead of a reckless driver.

The contribution of risk judgements on risky driving has been tested across different populations, and conclusions are inconsistent. Using absolute risk measures, Cohn et al. (1995) have suggested that once people perceive themselves as being susceptible to road crashes, they form intentions to take preventive actions. As such, threat perceptions would provide a motivating force leading to drive safely. On the contrary, the less drivers perceive risk in a given situation, the more likely they are to adopt risky behaviors (Lund \& Rundmo, 2009). Using comparative risk measures, some studies have found that comparative optimism reduces the likelihood of adopting safe behaviors (Delhomme, 2000; Delhomme \& Meyer, 1999; Klein, 1997; McKenna, Stanier, \& Lewis, 1991) and thereby undermines the effectiveness of educational measures. However, in regards to specific risks, comparative optimism can be ordinally accurate (Radcliffe \& Klein, 2002), and thus realistic. Indeed, people often attend to their risk-relevant behaviour when making comparative risk judgements, so that giving lower personal risk ratings can be related to safe behaviors. In the field of road traffic, such a realism has been mainly shown among motorcyclists (Rutter et al., 1998), cyclists (Martha \& Delhomme, 2009), and drivers (Causse et al., 2005; Delhomme, 2000; Delhomme et al., 2009; Meyer \& Delhomme, 2000).

In a previous study, Delhomme et al. (2009) examined comparative judgements about road-traffic risks inherent in speeding among young drivers, a specific population having a high risk of being involved in crashes (Twisk, Gregersen, Assailly, et al., 2006). Focusing on comparative judgements about the risk of sanctions and the risk of causing an automobile crash because of speeding, Delhomme et al. (2009) observed that the drivers' comparative risk judgements were realistic, i.e., participants who expressed comparative optimism reported 
less driving-related sensation seeking (DRSS, Taubman, Mikulincer, \& Iram, 1996, cited by Yagil, 2001) and less extreme speeding behaviors, than participants expressing similarity judgements or comparative pessimism.

In line with the results of Delhomme et al. (2009), the objective of the present study was to examine whether the realism of judgements about speeding risks could be found among an at-risk driver population made of traffic regulation offenders taking a driving licence points recovery course, considering both absolute and comparative judgements. In the literature, course takers have been described as being different from the general population of drivers (Nallet, Bernard, Gadegbeku, et al., 2010), since they drive more, commit more violations, more often have powerful cars, and more frequently describe their driving as sporty. As regards with their risk judgements, Nallet, Bernard, and Chiron (2008) showed that a significant proportion (24\%) of male course takers assess their own driving as being less dangerous than other drivers. Given the well-established link between sanctions and crashes and injuries (Campbell \& Stradling, 2003), such comparative risk judgements can be considered as unrealistic. While the study of Nallet et al. (2008) has assessed course takers' comparative risk judgements at the general level, measuring how dangerous individuals perceived their own driving in comparison with that of other French drivers, in our study we investigated absolute and comparative risk judgements with regards to specific risks related to speeding. We focused on speeding since it is the most frequent traffic violation (Moget, 1980; Nallet et al., 2010; West et al., 1993), it is related to increased risk of a crash (Aarts \& Schagen, 2006; Elliott, Armitage, \& Baughan, 2003), and it is a way of adapting to traffic systems and of managing interactions with other road users (Delhomme, 2008). In order to look at how realistic course takers' absolute and comparative (in reference to the estimated risks of average same-age drivers) risk judgements were, we measured the relationships between absolute and comparative judgements of speeding risks and self-reported speeding 
behavior. Self-reported speeding has been positively related to real speeding behavior (Aberg et al., 1997; Haglund \& Aberg, 2000; Haglund \& Aberg, 2002), while this link is more likely to be observed for rural than for urban areas (Fildes, Rumbold, \& Leening, 1991). Moreover, speeding remains stable over time for a given type of road (Ahlin, 1979). We also measured the relationship between absolute and comparative judgements of speeding risks and DRSS.

In line with the large body of studies who have shown that most of road users exhibit comparative optimism, we hypothesized that most of the course takers would express comparative optimism with regard to speeding-ticket risk (H1a), and speeding-induced crash risk (H1b). Given that people can attend to their risk-relevant behaviour when assessing their absolute and comparative risks, we also hypothesized that course takers' absolute and comparative risk judgments would be realistic. More precisely, we expected that course takers would rate their speeding-ticket risks ( $\mathrm{H} 2 \mathrm{a})$ and their speeding-induced crash risk (H2b) as being higher when their self-reported speeding and their DRSS were in fact higher. Their comparative optimism with regard to speeding-ticket risk (H3a) and speeding-induced crash risk $(\mathrm{H} 3 \mathrm{~b})$ was hypothesized to be related to a lower propensity to report the intention to speed, speeding behaviors in the past, and DRSS, while comparative pessimism was hypothesized to be related to high self-reported speeding and DRSS scores.

\section{Method}

\subsection{Participants}

The sample comprised 539 drivers participating in training rehabilitation courses between March and July 2008. On average, there are 16 participants, between 9 and 20, per course. In accordance with recent studies carried among course takers (Delhomme, Grenier, \& Kreel, 2008; Delhomme, Kreel, \& Ragot, 2008; Nallet et al., 2008; 2010), a large majority 
(85\%) of participants were men. They averaged 36.8 years of age $(S D=13.1$, range $18-81)$. For the purpose of the present study, and in order to compare our results with those of the study of Delhomme et al. (2009), analyses were conducted separately among young course takers, namely the course takers who were $18-25$ years old $(n=130)$ like the respondents of the Delhomme et al. (2009)' survey, and the others $(n=409)$, namely the course takers who were more than 25 years old. Young course takers had obtained their driver's license at a mean age of 3.6 years ago $(S D=2.1$, range $0-7)$, reported driving about 29700 kilometers per year $($ median $=20000, S D=24800)$, and possessed a mean number of points currently held on their driver's license of 2.6 (median $=2.0, S D=1.6)$. Among young course takers, $44.6 \%$ $(n=58)$ had been involved in at least one traffic crash and $68.7 \%(n=88)$ had received a ticket for speeding within the past 12 months (mean number of tickets received for speeding = 1.5 , median $=1.0, S D=1.2$ ). The more than 25 years old course takers had obtained their driver's license at a mean age of 20.8 years ago $(S D=11.7$, range $1-58)$, reported driving about 36900 kilometers per year $($ median $=25000, S D=32900)$, and possessed a mean number of credits points of 3.6 (median $=3.0, S D=2.0$ ). Among the more than 25 years old course takers, $30.3 \%(n=124)$ had been involved in at least one traffic crash and $83.4 \%(n=$ 342) had received a ticket for speeding within the past 12 months (mean number of tickets received for speeding $=2.4$, median $=2.0, S D=2.1$ ). Speeding represents the most prevalent violation among both sub-samples.

\subsection{Procedure}

The courses took place in 5 French centers of different regions (Aquitaine, Ile de France, and Rhône-Alpes). During the courses, the instructors follow a programme fixed at a national level divided into several modules presented in the two-day course. At the beginning of the first day, and prior to the sessions, the Psychologist Instructors invited all course takers 
to briefly introduce themselves and to give some information on the type of violation for which they have been sanctioned. Then, all course takers were invited to take part in a study investigating driving attitudes, and were assured that their answers would be treated anonymously. Professional investigators administered the self-reported questionnaire in the presence of the psychologist instructors who run the training rehabilitation courses.

\subsection{Measures}

The self-reported questionnaire comprised five sections. In the first section, participants had to read a scenario on speeding and answer questions while imagining themselves in the following scenario: "You are driving straight ahead in a lane where the speed limit is $90 \mathrm{~km} / \mathrm{h}$ and traffic is flowing."

The second section was used to gather self-reported speeding data. The behavioral intention to speed was measured by asking the participants their preferred speed, as well as the highest speed at which they intended to drive during the next 12 months when driving in the situation described above. Then their past speeding behavior was measured by asking them to report their preferred speed and the highest speed at which they had actually driven within the past 12 months in the same driving situation. While shorter periods such as 1month (Elliott, Thomson, Robertson, et al., 2013) or 3-month (Elliott et al., 2005) period could be used to measure speeding intention as well as past speeding behaviours, in the present study we chose a 12-month period as it allows to neutralize the possible effect of seasons on speeding.

The third section measured absolute and comparative risk judgements. The measures used were the perceived probability of obtaining a speeding ticket and the perceived probability of causing a traffic crash because of speeding. Comparative judgements of speeding risks were collected using the indirect comparative risk measures that require separate judgements of self 
(one's own absolute risk) and other (the average same-sex and same-age driver's absolute risk). Both direct and indirect comparative measures have been commonly employed in the literature (Causse et al., 2005; Helweg-Larsen \& Shepperd, 2001). All the items were rated on a scale ranging from1 (low perceived probability) and 5 (high perceived probability). Indirect comparative risk was computed as a difference score (average same-sex and same-age driver's absolute risk - own absolute risk), so that positive score indicated comparative optimism, a rating of 0 indicated similarity judgements, and negative scores indicated comparative pessimism. While some studies have shown that the evaluation order (self before other, versus other before self) has no influence on the score of comparative optimism (Perloff \& Fetzer, 1986), other studies have shown a greater comparative optimism using the other/self than the self/other condition (Hoorens \& Buunk, 1993; Otten \& Van der Pligt, 1996). Moreover, the recent study of Spitzenstetter and Schimchowitsch (2012) showed that the two evaluation orders do not correspond to strictly equivalent procedures; the other/self order requires extra cognitive effort (i.e., a higher response time) and leads to greater comparative optimism levels. Thus, in order to control the putative effect of the presentation order of the items measuring course takers' perception of their own risks and course takers' perception of the risks of the average same-sex and same-age driver, we randomly changed the presentation order of these items.

In the fourth section, DRSS was measured using the French version (Delhomme, 2002; Cronbach's alpha $=0.68)$ of Taubman et al.'s $(1996)$ scale $($ Cronbach's alpha $=0.84)$. In the present study, the Cronbach's alpha of the scale was 0.63 . While this coefficient can be considered as relatively low and thus "questionable" (George \& Mallery, 2003), it remains in line with those reported in previous studies among French Drivers (e.g., 0.66 in the Delhomme et al. (2012) and Cristea, Paran \& Delhomme (2013)' studies). 
In the last section, participants reported personal identification variables such as age, sex, driving experience (i.e., number of years since obtaining a driver's license), number of kilometers driven over the last 12 months, number of times ticketed for a traffic violation and types of offenses, and number of times involved in a traffic crash within the last 12 months. The validity of 12-month self-reported data for both on-road crashes and traffic offences has been confirmed by the study of Boufous, Ivers, Senserrick, et al. (2010).

\subsection{Statistical Analyses}

First, we measured sex and age categories differences with regard to: 1) self-reported past preferred speed, past fastest speed, preferred speed and fastest speed at which course takers intended to drive, and DRSS; and 2) absolute and comparative risk judgements. For this purpose, we conducted two multivariate analyses of variance (MANOVAs), followed by univariate analyses (ANOVAs) carried out to test which dependent variables were responsible for the differences in mean vectors that were shown in MANOVAs.

Second, we conducted paired-samples T tests in order to examine evidence of $\mathrm{CO}$ regarding speeding-ticket risks and speeding-induced crash risk, and the putative difference between the participants' risk judgements regarding these two risks. We also used Pearson's $c h i^{2}$ while taking the phi value into account to compare the proportion of participants who expressed comparative optimism, similarity judgements, or comparative pessimism, according to sex and age category.

Third, Pearson correlations were computed to identify the relationships between selfreported speeding, DRSS, absolute and comparative risk judgements.

Finally, general linear models were used to test the overall effects of comparative risk judgements, sex, and age categories on self-reported speeding and DRSS, controlling for 
mileage driven.

\section{Results}

\subsection{Self-reported speeding, DRSS, and crash experience according to sex and age category}

Descriptive statistics and statistical differences according to sex and age categories in preferred past speed, fastest past speed, preferred speed and fastest speed at which course takers intended to drive, and DRSS, are provided in Table 1.

\section{$\underline{\text { Insert Table } 1 \text { about here }}$}

MANOVA revealed significant age categories differences on the dependent variables (Wilks' Lambda $F_{(5,539)}=7.8, p<0.001$, partial $\left.\eta^{2}=0.07\right)$. There was a difference between young course takers and the others on fastest past speed $\left(F_{(1,539)}=5.9, p<0.02\right.$, partial $\eta^{2}=$ $0.01)$, fastest speed at which course takers intend to drive $\left(F_{(1,539)}=4.2, p<0.05\right.$, partial $\eta^{2}=$ $0.01)$, and DRSS $\left(F_{(1,539)}=33.0, p<0.001\right.$, partial $\left.\eta^{2}=0.06\right)$. MANOVA revealed no significant sex differences and no interaction between sex and age categories. Among the young course takers sub-sample, the only observed sex difference concerned fastest past speed, as men reported higher fastest past speed than women $\left(t_{(130)}=2.5, p<0.05\right)$. Among the other course takers sub-sample, men reported higher fastest past speed $\left(t_{(409)}=2.6, p<\right.$ $0.05)$, and higher DRSS $\left(t_{(409)}=3.7, p<0.001\right)$. Table 1 also provides proportion of participants having been involved in at least one traffic crash within the last 12 months. Young course takers are more likely than the others to report such experience $\left(\operatorname{chi}^{2}{ }_{(2)}=9.9, p<\right.$ 0.001, Phi $=0.14)$. Among the other course takers sub-sample, a higher proportion of men have been involved in a traffic crash in comparison to women $\left(\operatorname{chi}^{2}(2)=7.1, p<0.01, P h i=\right.$ 0.13), while there is no sex difference among the young course takers sub-sample. 


\subsection{Absolute and comparative risk judgements according to sex and age}

Descriptive statistics and statistical differences according to sex and age categories in absolute and comparative judgements about speeding-ticket risk, and absolute and comparative judgements about the risk of causing a crash because of speeding, are provided in Table 2.

\section{Insert Table 2 about here}

MANOVA revealed significant age categories differences on the dependent variables (Wilks' Lambda $F_{(4,539)}=5.04, p<0.001$, partial $\eta^{2}=0.04$ ). While there is no difference between young course takers and the others regarding absolute risk judgements, young course takers perceived more risk for the average same-sex and same-age driver in comparison to the other course takers, whatever the risk: speeding-ticket risk $\left(F_{(1,539)}=15.59, p<0.001\right.$, partial $\left.\eta^{2}=0.04\right)$, or speeding-induced crash risk $\left(F_{(1,539)}=38.86, p<0.001\right.$, partial $\left.\eta^{2}=0.06\right)$. Young course takers expressed also more comparative optimism than the other course takers regarding speeding-ticket risk $\left(F_{(1,539)}=7.7, p<0.01\right.$, partial $\left.\eta^{2}=0.02\right)$ and regarding the risk of causing a crash because of speeding $\left(F_{(1,539)}=10.8, p<0.001\right.$, partial $\left.\eta^{2}=0.02\right)$.

MANOVA revealed no significant sex differences and no interaction between sex and age categories. The only sex difference is observed among the other course takers sub-sample and concerned absolute and comparative judgements about the risk of causing a crash because of speeding, as men reported higher absolute judgements $\left(t_{(409)}=2.02, p<0.05\right)$ and lower comparative optimism $\left(t_{(409)}=2.15, p<0.05\right)$ regarding the risk of causing a crash because of speeding than women.

There is evidence of comparative optimism for both subsamples. For young course takers, paired-sample $\mathrm{T}$ tests revealed that their risk judgement was lower for oneself than for the average same-sex and same-age driver, whatever the risk: speeding-ticket risk $\left(t_{(130)}=\right.$ 
$10.35, p<0.001)$ and speeding-induced crash risk $\left(t_{(130)}=9.63, p<0.001\right)$. comparative optimism was also observed among the other course takers, for speeding-ticket risk $\left(t_{(409)}=\right.$ $8.82, p<0.001)$ as well as for speeding-induced crash risk $\left(t_{(409)}=12.32, p<0.001\right)$.

Table 2 also mentions the proportion of participants expressing comparative optimism, similarity judgements, or comparative pessimism. Concerning comparative judgements about speeding-ticket risk, there is a difference between young course takers and the others $\left(\operatorname{chi}^{2}{ }_{(2)}=\right.$ $14.73, p<0.001, P h i=0.16)$, as young course takers were more likely $(66.7 \%, n=86)$ to express comparative optimism than the other course takers $(47.3 \%, n=192)$ and were less likely to express $\mathrm{SJ}(23.3 \%, n=30)$ than the other course takers whose $37.2 \%(n=151)$ expressed similarity judgements. There is no difference between men and women in comparative judgements about the risk of being ticketed for speeding among the young course takers sub-sample, while among the others course takers sub-sample, women were more likely to express comparative pessimism and less likely to express similarity judgements than men $\left(\operatorname{chi}^{2}{ }_{(2)}=11.8, p<0.01, P h i=0.17\right)$.

Concerning comparative judgements about the risk of causing a crash because of speeding, there is no difference between young course takers and the others. Among young course takers, there is no difference between men and women in comparative judgements about the risk of causing a crash because of speeding, while among the other course takers, women were more likely to express comparative optimism and less likely to express similarity judgements in comparison with men $\left(\operatorname{chi}^{2}(2)=6.33, p<0.05, P h i=0.12\right)$.

The presentation order of the items measuring course takers' perception of their own risks and course takers' perception of the risks of the average same-sex and same-age driver had no effect on any comparative risk judgements scores.

3.3. Relationships between self-reported speeding, driving related sensation seeking, 
absolute and comparative risk judgements.

Insert Table 3 about here

Correlations among the measures are shown in Table 3. Among young course takers, there is a significant association between absolute judgements regarding speeding-ticket risk and speeds at which course takers intended to drive within the next 12 months ( $r \geq 0.19, p<0.05$ ), while there is no association between absolute or comparative judgements regarding crashrisk and self-reported speeds or DRSS. Among the other course takers, there are significant associations $(r \geq 0.14, p<0.01)$ between absolute judgements regarding speeding-ticket risk and fastest past speed, preferred and fastest speeds at which course takers intended to drive, and DRSS. Absolute or comparative judgements regarding crash-risk were not related to selfreported speeds or DRSS.

3.4. Self-reported speeding and driving related sensation seeking according to risk comparative judgements

\subsubsection{Comparative judgements of speeding-ticket risk}

\section{$\underline{\text { Insert Table } 4 \text { about here }}$}

Table 4 gives the descriptive data (means and $S D s$ ) for men and women, according to age categories, comparative judgements about the risk of sanctions, behavioral intentions to speed, self-reported past speeding, and DRSS.

In terms of DRSS $\left(R^{2}=0.14, F_{(11,539)}=7.20, p<0.001\right)$, young course takers reported higher DRSS than the other course takers $\left(F_{(1,539)}=15.1, p<0.001\right.$, partial $\left.\eta^{2}=0.03\right)$. There was no difference between the risk-judgement groups, nor between men and women. Mileage driven and the interaction between the independent variables were not significant.

Regarding preferred past speed $\left(R^{2}=0.001, F_{(11,539)}=1.04, p>0.05\right)$, all independent 
variables were not significant.

Regarding fastest past speed $\left(R^{2}=0.09, F_{(11,539)}=5.03, p<0.001\right)$, women reported lower speeds than men $\left(F_{(1,539)}=4.4, p<0.05\right)$, despite the small size of this sex effect (partial $\left.\eta^{2}=0.01\right)$. The interaction of age categories and risk comparative judgements has a small but significant effect $\left(F_{(2,539)}=3.0, p<0.05\right.$, partial $\left.\eta^{2}=0.01\right)$, as among the more than 25 years old course takers $\left(F_{(2,539)}=5.33, p<0.01\right)$, those who expressed comparative pessimism reported higher fastest speed than those who expressed comparative optimism $(p<$ $0.01)$ or similarity judgements $(p<0.05)$.

Regarding preferred speed at which course takers intended to drive, all independent variable were not significant $\left(R^{2}=0.001, F_{(11,539)}=0.93, p>0.05\right)$.

Regarding fastest speed at which course takers intended to drive $\left(R^{2}=0.07, F_{(11,539)}=\right.$ 3.6, $p<0.05)$, there was a small but significant effect of interaction of age categories and risk comparative judgements group $\left(F_{(2,539)}=2.9, p<0.05\right.$, partial $\left.\eta^{2}=0.01\right)$, as among the more than 25 years old course takers $\left(F_{(2,539)}=4.77, p<0.01\right)$, those who expressed comparative pessimism reported higher fastest speed than those who expressed comparative optimism $(p<$ $0.01)$

3.4.2. Comparative judgements of speeding-induced crash risk

\section{$\underline{\text { Insert Table } 5 \text { about here }}$}

Table 5 gives the descriptive data (means and $S D s$ ) for men and women, according to their age categories and their comparative judgements about the risk of causing a crash because of speeding, for the behavioral intention to speed, self-reported past speeding, and DRSS.

In terms of DRSS $\left(R^{2}=0.13, F_{(11,539)}=7.57, p<0.001\right)$, young course takers reported higher DRSS than the other course takers $\left(F_{(1,539)}=26.4, p<0.001\right.$, partial $\eta^{2}=$ 
$0.05)$. There was an effect of interaction between sex and age categories $\left(F_{(2,539)}=4.83, p<\right.$ 0.05 , partial $\eta^{2}=0.01$ ), as among the more than 25 years old course takers, men reported higher DRSS than women $\left(t_{(406)}=3.29, p<0.001\right)$, while there is no difference between men and women among the young course takers. All the other independent variables were not significant.

Regarding preferred past speed $\left(R^{2}=0.001, F_{(11,539)}=0.81, p>0.05\right)$, all independent variables were not significant.

Regarding fastest past speed $\left(R^{2}=0.07, F_{(11,539)}=3.51, p<0.001\right)$, women reported lower speeds than men $\left(F_{(1,539)}=4.8, p<0.05\right.$, partial $\left.\eta^{2}=0.01\right)$. All the other independent variables were not significant.

Regarding preferred speed $\left(R^{2}=0.01, F_{(11,539)}=1.05, p>0.05\right)$ and fastest speed $\left(R^{2}=\right.$ $\left.0.01, F_{(11,539)}=1.05, p>0.05\right)$ at which course takers intended to drive, all independent variables were not significant.

\section{Discussion}

The present study focused on absolute and comparative judgements about the risk of sanctions and the risk of causing an automobile crash because of speeding, among French regulation offenders attaining rehabilitation training courses. In line with the results of Delhomme et al. (2009), we aimed to measure the realism (Delhomme \& Meyer, 1999; Rutter et al., 1998) of participants' judgements regarding speeding risks.

The results showed that course takers' absolute judgements regarding speeding-ticket risk were realistic: more course-takers had the intention to drive fast and reported drivingrelated sensation-seeking (DRSS), more they evaluated themselves as being at risk of having 
a speeding-ticket, which lends support to our second hypothesis (H2a). While most of the course takers expressed comparative optimism with regard to the risk of sanction (supporting our first hypothesis H1a), the more than 25 years old course takers who expressed comparative pessimism reported higher speed at which they intended to drive. Hence, the realism was also observed when considering comparative judgements regarding speedingticket risk (supporting our third hypothesis, H3a), but only among the more than 25 years old course takers who seem to be well aware of their standing on the risk dimension with regard to speeding ticket in comparison to the average individual. Among young course takers, the absence of realism in comparative judgements about speeding-ticket risk can be explained by the fact that their comparative optimism regarding speeding-ticket risk was due to an overestimation of risk for others, but not an underestimation of risk for themselves: they perceived themselves as being at risk of being sanctioned, but perceived others as being at an even greater risk. This phenomenon is in line with the representativeness heuristic (Shepperd et al., 2002; Weinstein, 1980) that could have led young course takers to compare themselves to a stereotyped exemplar or general prototype of high-risk driver rather than a literal average target.

There is no realism in course takers' absolute judgements of having a crash, whatever the age category of the participants. Hence, our hypothesis concerning the realistic nature of course takers' absolute judgements was confirmed regarding speeding-ticket risk (H2a), but not regarding speeding-induced crash risk $(\mathrm{H} 2 \mathrm{~b})$. Several elements can explain this result. First, while personal experience with an undesirable event is supposed to diminish comparative optimism for that event (Harris, 2007), maybe course takers have not had enough crash experience (as a whole, only $33 \%$ have had a crash experience) to be aware of the link between their speeding behaviour and their probability to be involved in a road crash. Given their lack of crash experience, they probably bet on the absence of occurrence of accidents 
(Fuller, 1991). Moreover, there are many underlying causes of road crashes, so that one could think that his/her probability to be involved in a crash is not due only to his/her own driving behaviour such as speeding. Nevertheless, the absence of realism in course takers' absolute judgements of having a crash constitutes a critical result, above all among young course takers who are at greater risk in comparison with the more than 25 years old course takers. Indeed, young course takers reported higher past speed, had the intention to drive faster in the future, and expressed more driving-related sensation seeking (DRSS) scores. They were also more likely to have experienced at least one car crash within the past 12 months, which lends support to the well known link between drivers' crash experience, speeding (e.g., Siskind et al., 2011), and sensation-seeking, whether this personality trait was measured with a no domain-specific scale (Constantinou et al., 2011), or with a driving context specific scale (Delhomme, Chaurand, \& Paran, 2012).

Most of the course takers expressed comparative optimism with regard to the risk of causing a car crash because of speeding (which lends support to our first hypothesis, H1b). It is interesting to note that among the more than 25 years old course takers, women were more likely than men to express comparative optimism, and less likely to report having been involved in a traffic crash within the last 12 months. Hence, among the more than 25 years old course takers, when considering gender differences in both comparative judgements to the risk of causing a car crash, and crash experience, the higher propensity of women to express comparative optimism appeared somewhat realistic compared to men. However, among the whole sample, there is no link between comparative judgements regarding speeding-induced crash risk and self-reported speeds and DRSS, whatever the age category of the participants (hypothesis $\mathrm{H} 3 \mathrm{~b}$ was thus not confirmed).

Among the more than 25 years old course takers, the realism of risk comparative judgements depends on the type of risk judgements, since judgements regarding speeding- 
ticket risk were the only ones to be related to self-reported speeds and DRSS. As we have supposed above, a possible explanation for this difference in the realism of comparative judgements of speeding-ticket risk and speeding-induced crash risk lies in the experience with speeding-tickets, which concerned a large majority (83\%) of the more than 25 years old course takers, while a minority $(<33 \%)$ had a crash experience.

When comparing self reported speeding and DRSS of young course-takers in our study, and those of young drivers in the study of Delhomme et al. (2009), it is interesting to note that course takers reported higher DRSS $(2.7 v s<2.4$ in the study of Delhomme et al., 2009). They also reported lower preferred past speeds and lower preferred speeds at which they intended to drive $(95.5 \mathrm{~km} / \mathrm{h}$ and $92.1 \mathrm{~km} / \mathrm{h} v s 100.7 \mathrm{~km} / \mathrm{h}$ and $99.9 \mathrm{~km} / \mathrm{h}$, respectively), whereas they reported higher fastest past speeds and higher fastest speeds at which they intended to drive $(141.4 \mathrm{~km} / \mathrm{h}$ and $120.8 \mathrm{~km} / \mathrm{h}$ vs $113.7 \mathrm{~km} / \mathrm{h}$ and $111.1 \mathrm{~km} / \mathrm{h}$, respectively). It means that on the one hand course takers in our study used to comply with speed limit, or at least used to slightly exceed the speed limit, probably because a large majority (about 69\%) of them have been sanctioned for speeding within the last 12 months, and because of the growing involvement of central government in enforcement since the implantation in 2002 of the first automated traffic control systems. On the other hand, young course takers' fastest speeds made them stand out from young drivers in the study of Delhomme et al. (2009), since their fastest past speeds and their fastest speed at which they intended to drive were particularly high.

Potential interventions to prevent youthful excessive speeding can target one or more of the factors that influence such risky behaviour. Among these factors, while comparative optimism seems generally resilient to change (Shepperd et al., 2003), absolute risk perception can be changed, thus providing opportunities for intervention (Shope, 2006). The challenge is to diminish any discrepancy between perceived and objective speeding-related risks. The 
media, both advertising and entertainment, could provide good avenues for interventions (Shope, 2006). However, researchers have shown that interventions only temporarily decrease optimism: although people are capable to making more realistic judgements, when given the opportunity they make downward comparisons, actively flashing a prototype which is more at risk than the self (Perloff \& Fetzer, 1986). Moreover, people may have the tendency to perceive a message as being more relevant to, and exert a greater influence on, others than upon themselves, demonstrating what is known as the third-person effect (Davison, 1983; Lewis, Watson, \& Tay, 2007; Meyer, 1995). In the field of road safety, this phenomenon is particularly observed among males who do not intend to obey the speed limits (Lewis et al., 2007). Hence, safety education should insist on speeding-related risks in small groups during classes, obviously during the rehabilitation training courses, but also and above all during the initial driver training. In France in 2009 the reformed theoretical driving test has included questions about detection of risks and risk perception, but it seems necessary to insist even more on this aspect during driving school classes.

\section{Conclusion}

While several studies have revealed realistic risk judgements among road users such as pedestrians (Castanier et al., 2012), cyclists (Martha \& Delhomme, 2009), motorcyclists (Rutter et al., 1998), or drivers (Delhomme et al, 2009), our results suggested that such realism is not systematic among a high-risk population such as young course-takers. This result was in line with that of Martha, Laurendeau, and Griffet (2010), who have shown that among high-risk takers such as high-risk sports practitioners, driving-related comparative risk judgements could be unrealistic. From an applied perspective, then, it is important to improve knowledge about the dangerousness of speeding among specific groups such as student 
drivers, and particularly among young traffic regulation offenders attaining a training rehabilitation course. Further research measuring risk judgements should be conducted both at the beginning and at the end of the course to evaluate to what extent such intervention can increase the realism of participants' risk judgements, or only at the end of an intervention in order to test its effect on the realism compared to a control/comparison group. 


\section{Acknowledgements}

The authors would like to thank G. Korn, A. Schamelhout, M-P Laurent, and A. Périchou, who took part in this research, as well as the anonymous reviewers for helpful suggestions on an earlier version of this paper. 


\section{References}

Aberg, L., Larsen, L., Glad, A., \& Beilinson, L. (1997). Observed vehicle speed and drivers' perceived speed of others. Applied Psychology: An International Review, 46, 287-302. DOI: 10.1111/j.1464-0597.1997.tb01231.x

Ahlin, F. J. (1979). An investigation into the consistency of drivers' speed choice. Toronto, Ontario: Department of Civil Engineering, University of Toronto.

Aarts, L., \& Schagen, I. (2006). Driving speed and the risk of road crashes: A review. Accident Analysis and Prevention, 38, 215-224. DOI: 10.1016/j.aap.2005.07.004

Boufous, S., Ivers, R., Senserrick, T., Stevenson, M., Norton, R., Williamson, A. (2010). Accuracy of slef-report of on-road crashes and traffic offences in a cohort of young drivers: the drive study. Injury Prevention, 16, A79-A80.

DOI:10.1136/ip.2010.029215.290

Campbell, M., \& Stradling, S. G. (2003). Factors influencing driver speed choices.

Behavioural Research in Road Safety XIII. London: Department for Transport.

Castanier, C., Paran, F., Delhomme, P. (2012). Risk of crashing with a tram: Perceptions of pedestrians, cyclists, and motorists. Transportation Research Part F: Traffic Psychology and Behaviour, 15, 387-394. DOI: 10.1016/j.trf.2012.03.001.

Causse, P., Delhomme, P., \& Kouabenan, R.D. (2005). Jugements comparatifs et absolus de deux risques routiers contexualisés et raisons invoquées quant à ces jugements.

Psychologie du Travail et des Organisations, 11, 191-208. DOI:

10.1016/j.pto.2005.07.006

Chaurand, N., \& Delhomme, P. (2013). Cyclists and drivers in road interactions: A comparison of perceived crash risk. Accident Analysis and Prevention, 50, 1176- 1184. DOI: 10.1016/j.aap.2012.09.005 
Cohn, L.D., Macfarlane, S., Yanez, C., \& Imai, W.K., (1995). Risk-perception: Differences between adolescents and adults. Health Psychology, 14, 217-222. DOI: 10.1037/02786133.14 .3 .217

Constantinou, E., Panayiotoua, G., Konstantinoua, N., Loutsiou-Ladda, A., \& Kapardis, A. (2011). Risky and aggressive driving in young adults: Personality matters. Accident Analysis and Prevention, 43, 1323-1331. Doi:10.1016/j.aap.2011.02.002

Cristea, M., Paran, F., Delhomme, P. (2013). Extending the theory of planned behavior: The role of behavioral options and additional factors in predicting speed behavior.

Transportation Research Part F: Traffic Psychology and Behaviour, 21, 122-132. DOI: 10.1016/j.trf.2013.09.009

Davison W.P. (1983). The third-person effect in communication. Public Opinion Quarterly, 47, 1-15. doi.org.lama.univ-amu.fr/10.1086/268763

Delhomme, P. (1991). Comparing one's driving with others': Assessment of abilities and frequency of offences, evidence for a superiority conformity bias? Accident Analysis and Prevention, 23, 493-508. DOI: 10.1016/0001-4575(91)90015-W

Delhomme, P. (2000). Optimisme comparatif chez les usagers de la route: une protection contre le risque ? [Comparative optimism of road users : A protection against risk ?]. Pratiques Psychologiques, 1, 99-109.

Delhomme, P. (2002). Croyances des jeunes automobilistes en matière de vitesse. Rapport final. [Young drivers' beliefs about speeding. Final Report]. Convention DSCRINRETS n00/010/T-étude No. 7, December 2002.

Delhomme, P., Chaurand, N., \& Paran, F. (2012). Personality predictors of speeding in young drivers: Anger vs. sensation seeking. Transportation Research Part F: Traffic Psychology and Behaviour, 15, 654-666. DOI: 10.1016/j.trf.2012.06.006 
Delhomme, P., Grenier, K., \& Kreel, V. (2008). Replication and extension: The effect of the commitment to comply with speed limits in rehabilitation training courses for traffic regulation offenders in France. Transportation Research Part F: Traffic Psychology and Behaviour, 11, 192-206. DOI: 10.1016/j.trf.2007.10.002

Delhomme, P., Kreel, V., \& Ragot, I. (2008). The effect of the commitment to observe speed limits during rehabilitation training courses for traffic regulation offenders in France. Revue Européenne de Psychologie Appliquée/ European Review of Applied Psychology, 58, 31-42. doi.org/10.1016/j.erap.2005.07.005

Delhomme, P., \& Meyer, T. (1999). Un instrument d'analyse: l'optimisme comparatif [A tool for analyses: Comparative optimism]. Risques, 39, 100-105.

Delhomme, P., Verlhiac, J.F., \& Martha, C. (2009). Are drivers' comparative risk judgements about speeding realistic? Journal of Safety Research, 40, 333-339. doi:10.1016/j.jsr.2009.09.003

Elliott, M.A., Armitage, C.J., Baughan, C.J. (2003). Drivers' compliance with speed limits: An application of the theory of planned behavior. Journal of Applied Psychology, 88, 964-972. DOI: 10.1037/0021-9010.88.5.964

Elliott, M.A, Armitage, C.J., Baughan, C.J. (2005). Exploring the beliefs underpinning drivers' intentions to comply with speed limits. Transportation Research Part F: Traffic Psychology and Behaviour, 8, 459-479. DOI: 10.1016/j.trf.2005.08.002

Elliott, M. A., Thomson, J. A., Robertson, K., Stephenson, C., \& Wicks, J. (2013). Evidence that changes in social cognitions predict changes in self-reported driver behavior: Causal analyses of two-wave panel data. Accident Analysis and Prevention, 50, 905-916. DOI: 10.1016/j.aap.2012.07.017

Fildes, B., Rumbold, G., \& Leening, A. (1991). Speed behaviour and drivers' attitude to speeding. Monash University, Report $\mathrm{n}^{\circ} 16$. 
Fuller, R. (1991). Behavior analysis and unsafe driving: Warning Learning trap ahead! Journal of Applied Behavior Analysis, 24, 73-75.

George, D., \& Mallery, P. (2003). SPSS for Windows step by step: A simple guide and reference. 11.0 update (4thed.). Boston: Allyn \& Bacon.

Haglund, M., \& Aberg, L. (2000). Speed choice in relation to speed limit and influences from other drivers. Transportation Research Part F: Traffic Psychology and Behaviour, 3, 39-51. doi.org/10.1016/S1369-8478(00)00014-0

Haglund, M., \& Aberg, L. (2002). Stability in drivers' speed choice. Transportation Research Part F: Traffic Psychology and Behaviour, 5, 177-188. doi.org/10.1016/S13698478(02)00016-5.

Harris, P. (2007). The impact of perceived experience on likelihood judgments for self and others: An experimental approach. European Journal of Social Psychology, 37, 141151. DOI: $10.1002 /$ ejsp.339

Harris, P., Middleton, W., \& Joiner, R. (2000). The typical student as an in group member: Eliminating optimistic bias by reducing social distance. European Journal of Social Psychology, 30, 235-255. DOI: 10.1002/(SICI)1099-0992(200003/04)30:2<235

Helweg-Larsen, M., \& Shepperd, J.A. (2001). Do moderators of the optimistic bias affect personal or target risk estimates? A review of the literature. Personality and Social Psychology Review, 5, 74-95. DOI: 10.1207/S15327957PSPR0501_5

Hoorens, V., \& Buunk, B. P. (1993). Social comparison of health risks: Locus of control, the person-positivity bias, and unrealistic optimism. Journal of Applied Social Psychology, 24, 291-202. DOI: 10.1111/j.1559-1816.1993.tb01088.x

Klein, W. M. (1997). Objective standards are not enough: Affective, self-evaluative, and behavioural responses to social comparison information. Journal of Personality and Social Psychology, 72, 763-774. DOI: 10.1037/0022-3514.72.4.763 
Lewis, I.M., Watson, B.C., Tay, R.S. (2007). Examining the effectiveness of physical threats in road safety advertising: the role of the third-person effect, gender, and age. Transportation Research Part F: Traffic Psychology and Behaviour, 10, 48-60 DOI:/10.1016/j.trf.2006.05.001

Lund, I., \& Rundmo, T. (2009). Cross-cultural comparisons of traffic safety, risk perception, attitudes and behaviour. Safety Science, 47(4), 547-553. DOI: 10.1016/j.ssci.2008.07.008

Machin, M.A., \& Sankey, K.S. (2008). Relationships between young drivers' personality characteristics, risk perceptions, and driving behaviour. Accident Analysis and Prevention, 40, 541-547. DOI: 10.1016/j.aap.2007.08.010

McKenna, F. P. (1993). It won't happen to me - unrealistic optimism or illusion of control. British Journal of Psychology, 84, 39-50.

McKenna, F. P., Stanier, R. A., \& Lewis, C. (1991). Factors underlying illusory selfassessment of driving skill in males and females. Accident Analysis and Prevention, 23, 45-52. DOI: 10.1016/0001-4575(91)90034-3

Martha, C., \& Delhomme, P. (2009). Risk comparative judgements while driving a car among experienced cyclists and non-cyclists. Transportation Research Part F: Traffic Psychology and Behaviour, 12, 256-263. DOI: 10.1016/j.trf.2008.11.004

Martha, C., Laurendeau, J., \& Griffet, J. (2010). Comparative optimism and risky road traffic behaviors among high-risk sports practitioners. Journal of Risk Research, 13, 429-444. DOI: $10.1080 / 13669870903169275$

Meyer, T. (1995). Vulnérabilité subjective à l'influence des medias: optimisme comparatif et assiduité visuelle. Cahiers Internationaux de Psychologie Sociale, 26, 9-28.

Meyer, T., \& Delhomme, P. (2000). Quand chacun pense être moins exposé que les autres aux risques mais plus réceptif aux messages de prévention pour la santé [When each 
person thinks he is less exposed to risks than others, but more receptive to health prevention messages]. Santé Publique, 12, 133-147.

Moget, M. (1980). Une contribution au problème du risque dans l'activité de conduite : Les mécanismes de régulation du « comportement de base » de l'usager de la route. [Contribution to the problem of risky driving: Regulation mechanisms of the "basic behaviour" of road user]. Institut National de Recherche sur les Transports et leur Sécurité, Arcueil, Rapport Interne.

Nallet, N., Bernard, M., \& Chiron, M. (2008). Individuals taking a French driving licence points recovery course: Their attitudes towards violations. Accident Analysis \& Prevention, 40, 1836-1843. DOI: 10.1016/j.aap.2008.08.014

Nallet, N., Bernard, M., \& Chiron, M. (2010). Self-reported road traffic violations in France and how they have changed since 1983. Accident Analysis \& Prevention, 42, 13021309. DOI: 10.1016/j.aap.2010.02.008

Nallet, N., Bernard, M., Gadegbeku, B., Supernant, K., \& Chiron, M. (2010). Who takes driving licence point recovery courses in France? Comparison between course-takers and ordinary drivers. Transportation Research Part F: Traffic Psychology and Behaviour, 13, 92-105. DOI: 10.1016/j.trf.2009.11.005

Observatoire national interministériel de sécurité routière (ONISR, 2012). Observatoire des vitesses année 2011. Url http://securite-routiere.gouv.fr/la-securite-routiere/lobservatoire-national-interministeriel-de-la-securite-routiere/bilans-annuels/bilansannuels-de-la-securite-routiere-en-france

Otten, W., \& van der Pligt, J. (1996). Context effects in the measurement of comparative optimism in probability judgments. Journal of Social and Clinical Psychology, 15, 80101. DOI: $10.1521 /$ jscp.1996.15.1.80

Parker, D., Manstead, S.R., \& Stradling, S.G. (1995). Extending the theory of planned 
behaviour: The role of personal norm. British Journal of Social Psychology, 34, 127137.

Perloff, L. S., \& Fetzer, B. K. (1986). Self-other judgments and perceived vulnerability to victimization. Journal of Personality and Social Psychology, 50, 502-510. DOI: $10.1037 / / 0022-3514.50 .3 .502$

Radcliffe, N.M., \& Klein, W.M.P. (2002). Dispositional, unrealistic, and comparative optimism: Differential relations with the knowledge and processing of risk information and beliefs about personal risk. Personality and Social Psychology Bulletin, 28, 836846. DOI: $10.1177 / 0146167202289012$

Ranby, K.W., Aiken, L.S., Gerend, M.A., \& Erchull, M.J. (2010). Perceived susceptibility measures are not interchangeable: absolute, direct comparative, and indirect comparative risk. Health Psychology, 29, 20-8. DOI: 10.1037/a0016623

Rutter, D. R., Quine, L., \& Albery, I. P. (1998). Perceptions of risk in motorcyclists: Unrealistic optimism, relative realism and predictions of behavior. British Journal of Psychology, 89, 681-96.

Shepperd, J.A., Carroll, P., Grace, J., \& Terry, M. (2002). Exploring the causes of comparative optimism. Psychologica Belgica, 42, 65-98. WOS:000179225100005

Shepperd, J.A., Helweg-Larsen, M., Ortega, L. (2003). Are comparative risk judgments consistent across time and events? Personality and Social Psychology Bulletin, 29, 1169-1180. DOI: 10.1177/0146167203254598

Shepperd, J.A., Klein, W.M.P., Waters, E.A., \& Weinstein, N.D. (2013). Taking Stock of Unrealistic Optimism. Perspectives on Psychological Science, 8, 395-411. DOI: $10.1177 / 1745691613485247$

Shope, J T. (2006). Influences on youthful driving behavior and their potential for guiding interventions to reduce crashes. Injury Prevention, 12, 9-14. 
DOI:10.1136/ip.2006.011874.

Siskind, V., Steinhardt, V., Sheehan, M., O’Connor, T., \& Hanks, H. (2011). Risk factors for fatal crashes in rural Australia. Accident Analysis and Prevention, 43, 1082-1088. DOI: 10.1016/j.aap.2010.12.016

Spitzenstetter, F., Schimchowitsch, S. (2012). Interdepency between risk assessments for self and other in the field of comparative optimism: the contribution of response times. Psychological Record, 62, 115-123. WOS:000300522400009

Taubman, O., Mikulincer, M., \& Iram, A. (1996). The cognitive, motivational and emotional system of driving. Research report, Department of Casualties and Road Safety of the Israeli Army, Israel.

Twisk, D., Gregersen, N.-P., Assailly, J.-P. et al. (2006). The road to safety; Young drivers, risks and effective countermeasures, OECD-ECMT Report. DOI: $10.1787 / 9789282113370-\mathrm{fr}$

Weinstein, N.D. (1980). Unrealistic optimism about future life events. Journal of Personality and Social Psychology, 39, 806-820. DOI: 10.1037/0022-3514.39.5.806

Weinstein, N.D. (1987). Unrealistic optimism about susceptibility to health problems: Conclusions from a community-wide sample. Journal of Behavioral Medicine, 10, 481500. DOI: 10.1007/BF00846146

Weinstein, N.D., \& Klein, W.M. (1996). Unrealistic optimism: Present and future. Journal of Social and Clinical Psychology, 15, 1-8. DOI: 10.1521/jscp.1996.15.1.1

West, R., French, D., Kemp, R., \& Elander, J. (1993). Direct observation of driving, self reports of driver behaviour, and crash involvement. Ergonomics, 36, 557-567. DOI: $10.1080 / 00140139308967912$ 
Yagil, D. (2001). Reasoned action and irrational motives: A prediction of drivers' intention to violate traffic laws. Journal of Applied Social Psychology, 31, 720-740. DOI:

10.1111/j.1559-1816.2001.tb01410.x 
Table 1

Description of course takers in terms of their self-reported speeding, DRSS, and crash experience

\begin{tabular}{|c|c|c|c|c|c|c|c|c|c|c|c|}
\hline \multirow[b]{3}{*}{ Measured variable } & \multicolumn{5}{|c|}{$\begin{array}{l}\text { Young course takers } \\
\qquad(\mathrm{n}=130)\end{array}$} & \multicolumn{5}{|c|}{$\begin{array}{l}\text { Other course takers } \\
\qquad(\mathrm{n}=409)\end{array}$} & \multirow{3}{*}{$\begin{array}{l}\text { P-value for difference } \\
\text { young/other course takers }\end{array}$} \\
\hline & \multicolumn{2}{|c|}{$\hat{\sigma}(\mathrm{n}=117)$} & \multicolumn{2}{|c|}{ 우 $(\mathrm{n}=13)$} & \multirow{2}{*}{$\begin{array}{l}\text { P-value for } \\
\text { difference } \delta / q\end{array}$} & \multicolumn{2}{|c|}{$\widehat{\partial}(\mathrm{n}=350)$} & \multicolumn{2}{|c|}{ ㅇ $(\mathrm{n}=59)$} & \multirow{2}{*}{$\begin{array}{l}\text { P-value for difference } \\
\partial / Q\end{array}$} & \\
\hline & Mean & (SD) & Mean & (SD) & & Mean & (SD) & Mean & (SD) & & \\
\hline Preferred past speed & 96 & 15.8 & 91.5 & 20.7 & ns & 97 & 16.8 & 94.5 & 17.3 & ns & ns \\
\hline Fastest past speed & 143.2 & 33.1 & 125 & 23 & $*$ & 126.4 & 30.5 & 117.9 & 22 & $*$ & $*$ \\
\hline $\begin{array}{l}\text { Preferred speed at which } \\
\qquad \text { drivers intend to drive }\end{array}$ & 92.2 & 13.3 & 91.5 & 17.2 & ns & 92 & 12.3 & 89.5 & 10.5 & ns & ns \\
\hline $\begin{array}{l}\text { Fastest past speed at which } \\
\text { drivers intend to drive }\end{array}$ & 121.7 & 28.8 & 112.3 & 16.9 & ns & 111.5 & 23.7 & 106.1 & 18.4 & ns & $*$ \\
\hline DRSS & 2.7 & 0.8 & 2.7 & 0.6 & ns & 2.2 & 0.7 & 1.8 & 0.6 & $* * *$ & $* * *$ \\
\hline Measured variable & $\%$ & $\mathrm{n}$ & $\%$ & $\mathrm{n}$ & & $\%$ & $\mathrm{n}$ & $\%$ & $\mathrm{n}$ & & \\
\hline Crash experience & 42.7 & 50 & 61.5 & 8 & ns & 32.9 & 112 & 15.5 & 9 & $* *$ & $* * *$ \\
\hline
\end{tabular}

q: Women. ${ }^{\lambda}$ : Men. Young course takers: course takers $\leq 25$ years old. Other course takers: course takers $>25$ years old. ${ }^{a}$ over the last 12 months (in km/h). ${ }^{b}$ within the next 12 months (in $\mathrm{km} / \mathrm{h}$ ). ${ }^{\mathrm{c}}$ Having been involved in at least one traffic crash within the last 12 months. DRSS: driving-related sensation-seeking. ${ }^{*} p<0.05$ (2-tailed).** $p<0.01$ (2-tailed). $* * * p<0.001$ (2-tailed). ns: non-significant. 
Table 2

Description of course takers in terms of their judgements about speeding-ticket risk and about the risk of causing a crash because of speeding

\begin{tabular}{|c|c|c|c|c|c|c|c|c|c|c|c|}
\hline \multirow[b]{3}{*}{ Measured variable } & \multicolumn{5}{|c|}{$\begin{array}{l}\text { Young course takers } \\
\qquad(\mathrm{n}=130)\end{array}$} & \multicolumn{5}{|c|}{$\begin{array}{l}\text { Other course takers } \\
\qquad(\mathrm{n}=409)\end{array}$} & \multirow{3}{*}{$\begin{array}{l}\text { P-value for difference } \\
\text { young/other course takers }\end{array}$} \\
\hline & \multicolumn{2}{|c|}{$\widehat{\partial}(\mathrm{n}=117)$} & \multicolumn{2}{|c|}{ ㅇ $(\mathrm{n}=13)$} & \multirow{2}{*}{$\begin{array}{l}\text { P-value for } \\
\text { difference } \delta / Q\end{array}$} & \multicolumn{2}{|c|}{$\widehat{\partial}(\mathrm{n}=350)$} & \multicolumn{2}{|c|}{$q(\mathrm{n}=59)$} & \multirow{2}{*}{$\begin{array}{l}\text { P-value for } \\
\text { difference } \hat{\delta} / Q\end{array}$} & \\
\hline & Mean & $(\mathrm{SD})$ & Mean & $(\mathrm{SD})$ & & Mean & $(\mathrm{SD})$ & Mean & $(\mathrm{SD})$ & & \\
\hline $\begin{array}{l}\text { Absolute risk judgement regarding } \\
\text { speeding-ticket }\end{array}$ & 2.87 & 1.3 & 2.92 & 1.32 & ns & 3.11 & 1.46 & 2.93 & 1.42 & ns & ns \\
\hline $\begin{array}{l}\text { Risk judgement regarding speeding- } \\
\text { ticket for the other drivers }\end{array}$ & 4.21 & 0.95 & 4.30 & 0.85 & ns & 3.77 & 1.25 & 3.62 & 1.23 & ns & $* * *$ \\
\hline $\begin{array}{l}\text { Comparative risk judgement } \\
\text { regarding speeding-ticket }\end{array}$ & 1.34 & 1.51 & 1.38 & 1.19 & ns & 0.66 & 1.49 & 0.69 & 1.69 & ns & $* *$ \\
\hline & $\%$ & $\mathrm{n}$ & $\%$ & $\mathrm{n}$ & & $\%$ & $\mathrm{n}$ & $\%$ & $\mathrm{n}$ & & \\
\hline $\mathrm{CO}$ regarding speeding-ticket risk & 65 & 76 & 83.3 & 10 & ns & 45.8 & 159 & 49.2 & 29 & ns & $* * *$ \\
\hline SJ regarding speeding-ticket risk & 23.9 & 28 & 16.7 & 2 & ns & 40.4 & 140 & 25.4 & 15 & $* *$ & $* *$ \\
\hline $\mathrm{CP}$ regarding speeding-ticket risk & 11.1 & 13 & 0 & 0 & ns & 13.8 & 48 & 25.4 & 15 & $* *$ & ns \\
\hline & & & & & & & & & & & \\
\hline
\end{tabular}




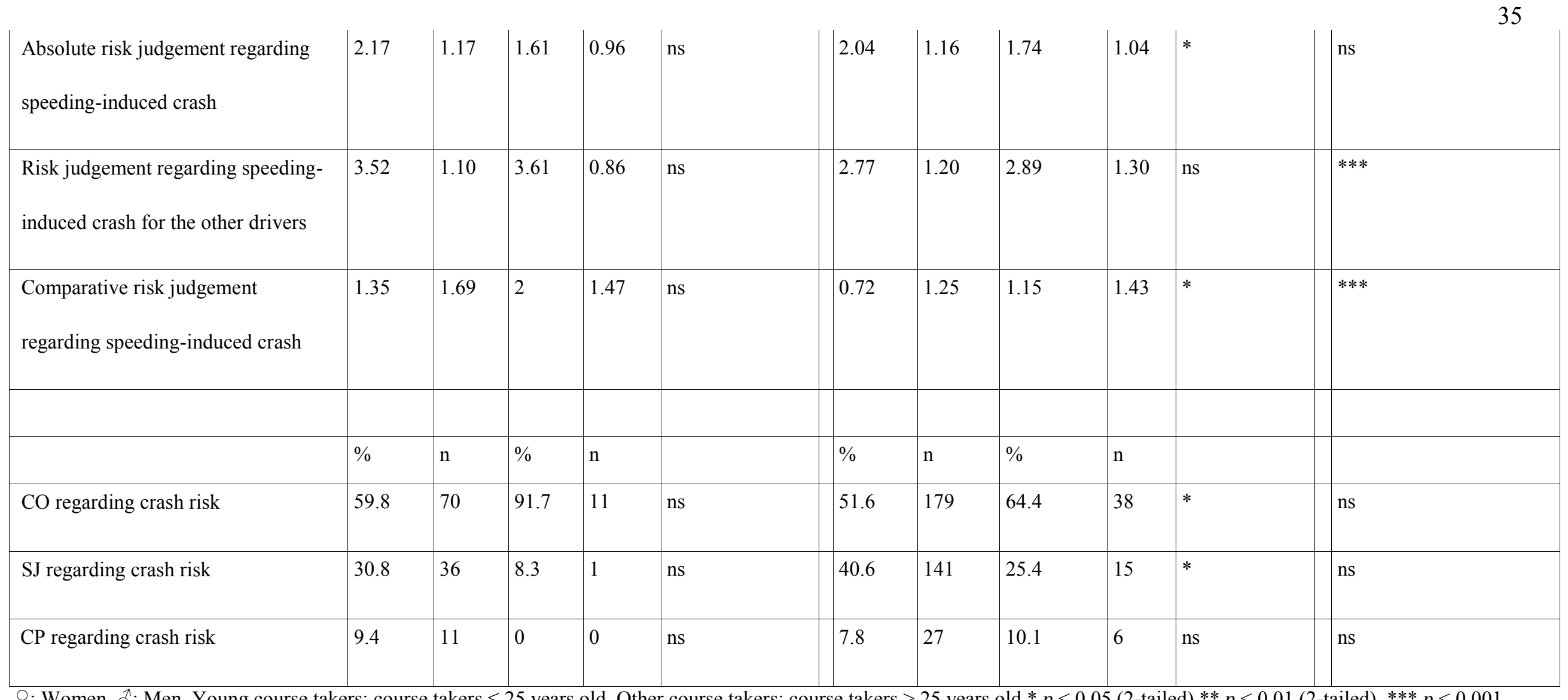

q: Women. $\delta^{\wedge}$ : Men. Young course takers: course takers $\leq 25$ years old. Other course takers: course takers $>25$ years old.* $p<0.05$ (2-tailed).** $p<0.01$ (2-tailed). ${ }^{* *} p<0.001$ (2-tailed). ns: non-significant. CO: comparative optimism. SJ: similarity judgements. CP: comparative pessimism. 
Table 3

Correlations between self-reported speeding, DRSS, absolute and comparative risk judgements.

\begin{tabular}{|c|c|c|c|c|c|c|c|c|c|c|c|}
\hline & & 1 & 2 & 3 & 4 & 5 & 6 & 7 & 8 & 9 & 10 \\
\hline \multirow[t]{2}{*}{ 1. Preferred past speed } & Young course takers & & & & & & & & & & \\
\hline & Other course takers & & & & & & & & & & \\
\hline \multirow{2}{*}{ 2. Fastest past speed } & Young course takers & $0.28 * * *$ & & & & & & & & & \\
\hline & Other course takers & $0.40 * * *$ & & & & & & & & & \\
\hline \multirow{2}{*}{$\begin{array}{l}\text { 3. Preferred speed at which course } \\
\text { takers intend to drive }\end{array}$} & Young course takers & $0.57 * * *$ & 0.22 * & & & & & & & & \\
\hline & Other course takers & $0.63 * * *$ & $0.34 * * *$ & & & & & & & & \\
\hline \multirow{2}{*}{$\begin{array}{l}\text { 4. Fastest past speed at which } \\
\text { course takers intend to drive }\end{array}$} & Young course takers & 0.12 & $0.62 * * *$ & $0.27 * *$ & & & & & & & \\
\hline & Other course takers & $0.31 * * *$ & $0.63 * * *$ & $0.38 * *$ & & & & & & & \\
\hline \multirow{2}{*}{ 5. DRSS } & Young course takers & -0.07 & 0.13 & -0.01 & 0.13 & & & & & & \\
\hline & Other course takers & $0.21 * * *$ & $0.25 * *$ & $0.26 * * *$ & $0.19 * *$ & & & & & & \\
\hline \multirow{2}{*}{$\begin{array}{l}\text { 6. Absolute risk judgement } \\
\text { regarding speeding-ticket }\end{array}$} & Young course takers & 0.01 & 0.10 & 0.21 * & 0.19 * & 0.04 & & & & & \\
\hline & Other course takers & 0.08 & $0.19 * *$ & $0.14 * *$ & $0.23 * *$ & $0.15 * *$ & & & & & \\
\hline \multirow{2}{*}{$\begin{array}{l}\text { 7. Risk judgement regarding } \\
\text { speeding-ticket for the other drivers }\end{array}$} & Young course takers & 0.09 & 0.02 & 0.01 & 0.03 & 0.06 & 0.15 & & & & \\
\hline & Other course takers & 0.08 & 0.08 & 0.05 & 0.06 & $0.16 * * *$ & $0.38 * * *$ & & & & \\
\hline 8. Comparative risk judgement & Young course takers & -0.02 & -0.09 & -0.12 & -0.15 & 0.01 & $-0.78 * *$ & $0.50^{* * *}$ & & & \\
\hline
\end{tabular}




\begin{tabular}{|c|c|c|c|c|c|c|c|c|c|c|c|}
\hline regarding speeding ticket & Other course takers & -0.01 & $-0.11 *$ & -0.09 & $-0.17^{* * *}$ & -0.04 & $-0.64 * * *$ & $0.46^{* * * *}$ & & & \\
\hline \multirow{2}{*}{$\begin{array}{l}\text { 9. Absolute risk judgement } \\
\text { regarding speeding-induced crash }\end{array}$} & Young course takers & -0.12 & 0.08 & 0.04 & 0.05 & 0.13 & $0.32 * *$ & -0.12 & $-0.35 * *$ & & \\
\hline & Other course takers & 0.01 & 0.05 & -0.02 & 0.05 & 0.05 & $0.31 * *$ & 0.06 & $-0.25 * *$ & & \\
\hline \multirow{2}{*}{$\begin{array}{l}\text { 10. Risk judgement regarding } \\
\text { speeding-induced crash for other } \\
\text { drivers }\end{array}$} & Young course takers & -0.02 & 0.12 & 0.09 & 0.01 & $0.26 * *$ & -0.06 & $0.35 * *$ & $0.28 * *$ & -0.12 & \\
\hline & Other course takers & -0.06 & -0.03 & -0.05 & -0.03 & 0.01 & 0.08 & $0.30 * * *$ & $0.17 * *$ & $0.41 * *$ & \\
\hline \multirow{2}{*}{$\begin{array}{l}\text { 11. Comparative risk judgement } \\
\text { regarding speeding-induced crash }\end{array}$} & Young course takers & 0.07 & 0.01 & -0.06 & -0.05 & 0.07 & $-0.26 * *$ & $0.31 * *$ & $0.43 * *$ & $-0.77 * *$ & $0.72 * *$ \\
\hline & Other course takers & -0.01 & -0.08 & -0.03 & -0.07 & -0.03 & $-0.20 * *$ & $0.23 * * *$ & $\mathbf{0 . 3 8} * *$ & $-0.50 * * *$ & $0.58 * *$ \\
\hline
\end{tabular}

Young course takers: course takers $\leq 25$ years old. Other course takers: course takers $>25$ years old. ${ }^{a}$ over the last 12 months (in km/h). ${ }^{b}$ within the next 12 months (in

km/h). DRSS: driving-related sensation-seeking. ${ }^{*} p<0.05$ (2-tailed).** $p<0.01$ (2-tailed). ${ }^{* * *} p<0.001$ (2-tailed). ns: non-significant. 
Table 4

Mean differences in self-reported speeding and DRSS $(\mathrm{n}=539)$, by speeding-ticket-risk-judgment group (comparative optimism vs similarity judgements vs comparative pessimism), sex, and age categories

\begin{tabular}{|c|c|c|c|c|c|c|c|c|c|c|c|c|}
\hline & \multicolumn{4}{|c|}{$\mathrm{CO}(\mathrm{n}=279)$} & \multicolumn{4}{|c|}{$\mathrm{SJ}(\mathrm{n}=180)$} & \multicolumn{4}{|c|}{$\mathrm{CP}(\mathrm{n}=76)$} \\
\hline & \multicolumn{2}{|c|}{$\operatorname{Men}(n=235)$} & \multicolumn{2}{|c|}{ Women $(n=44)$} & \multicolumn{2}{|c|}{$\operatorname{Men}(n=167)$} & \multicolumn{2}{|c|}{ Women $(n=13)$} & \multicolumn{2}{|c|}{$\operatorname{Men}(n=61)$} & \multicolumn{2}{|c|}{ Women $(\mathrm{n}=15)$} \\
\hline & $\begin{array}{l}Y(n= \\
76)\end{array}$ & $\begin{array}{l}O \\
(n=159)\end{array}$ & $Y(n=11)$ & $O(n=33)$ & $Y(n=28)$ & $O(n=139)$ & $\mathrm{Y}(\mathrm{n}=2)$ & $O(n=11)$ & $Y(n=13)$ & $\mathrm{O}(\mathrm{n}=48)$ & $Y(n=0)$ & $O(n=15)$ \\
\hline Measured variable & $\begin{array}{l}\text { Mean } \\
(\mathrm{SD})\end{array}$ & $\begin{array}{l}\text { Mean } \\
(\mathrm{SD})\end{array}$ & $\begin{array}{l}\text { Mean } \\
(\mathrm{SD})\end{array}$ & $\begin{array}{l}\text { Mean } \\
(\mathrm{SD})\end{array}$ & Mean (SD) & $\begin{array}{l}\text { Mean } \\
(\mathrm{SD})\end{array}$ & Mean (SD) & Mean (SD) & Mean (SD) & Mean (SD) & & Mean (SD) \\
\hline DRSS & $\begin{array}{l}2.75 \\
(0.78)\end{array}$ & $\begin{array}{l}2.24 \\
(0.76)\end{array}$ & $\begin{array}{l}2.69 \\
(0.61)\end{array}$ & $\begin{array}{l}1.75 \\
(0.49)\end{array}$ & $3.00(0.79)$ & $\begin{array}{l}2.20 \\
(0.75)\end{array}$ & $2.57(0.60$ & $1.84(0.77)$ & $2.39(0.65)$ & $2.17(0.76)$ & & $2.17(0.76)$ \\
\hline Preferred past speed ${ }^{a}$ & $\begin{array}{l}96.11 \\
(16.49)\end{array}$ & $\begin{array}{l}97.10 \\
(15.38)\end{array}$ & $\begin{array}{l}95.00 \\
(21.38)\end{array}$ & $\begin{array}{l}94.64 \\
(17.02)\end{array}$ & $\begin{array}{l}94.70 \\
(10.93)\end{array}$ & $\begin{array}{l}96.36 \\
(17.65)\end{array}$ & $\begin{array}{l}95.00 \\
(7.07)\end{array}$ & $\begin{array}{l}94.50 \\
(15.71)\end{array}$ & $\begin{array}{l}95.00 \\
(19.30)\end{array}$ & $\begin{array}{l}101 \\
(18.22)\end{array}$ & & $\begin{array}{l}94.61 \\
(22.58)\end{array}$ \\
\hline Fastest past speed & $\begin{array}{l}143.4 \\
(35.3)\end{array}$ & $\begin{array}{l}124.1 \\
(35.5)\end{array}$ & $\begin{array}{l}124.1 \\
(23.5)\end{array}$ & $\begin{array}{l}111.4 \\
(22.0)\end{array}$ & $\begin{array}{l}146.7 \\
(29.5)\end{array}$ & $\begin{array}{l}125.3 \\
(31.2)\end{array}$ & $\begin{array}{l}130.0 \\
(28.3)\end{array}$ & $\begin{array}{l}122.7 \\
(14.0)\end{array}$ & $\begin{array}{l}134.6 \\
(26.6)\end{array}$ & $\begin{array}{l}138.1 \\
(25.8)\end{array}$ & & $\begin{array}{l}128.6 \\
(22.6)\end{array}$ \\
\hline $\begin{array}{l}\text { Preferred speed at which } \\
\text { course takers intend to drive }\end{array}$ & $\begin{array}{l}92.2 \\
(12.6)\end{array}$ & $\begin{array}{l}91.2 \\
(9.3)\end{array}$ & $\begin{array}{l}90.9 \\
(18.7)\end{array}$ & $89.0(9.7)$ & $90.6(12.7)$ & $\begin{array}{l}91.6 \\
(14.2)\end{array}$ & $95.0(7.0)$ & $87.2(12.7)$ & $94.6(18.5)$ & $95.6(15.0)$ & & $92.3(10.8)$ \\
\hline $\begin{array}{l}\text { Fastest past speed at which } \\
\text { course takers intend to drive }\end{array}$ & $\begin{array}{l}119.9 \\
(28.9)\end{array}$ & $\begin{array}{l}108.6 \\
(20.0)\end{array}$ & $\begin{array}{l}110.9 \\
(17.6)\end{array}$ & $\begin{array}{l}101.3 \\
(15.2)\end{array}$ & $\begin{array}{l}129.0 \\
(27.0)\end{array}$ & $\begin{array}{l}112.2 \\
(27.0)\end{array}$ & $\begin{array}{l}120.0 \\
(14.1)\end{array}$ & $\begin{array}{l}113.6 \\
(20.6)\end{array}$ & $\begin{array}{l}115.4 \\
(29.9)\end{array}$ & $\begin{array}{l}118.6 \\
(24.3)\end{array}$ & & $\begin{array}{l}111.3 \\
(20.9)\end{array}$ \\
\hline
\end{tabular}

CO: comparative optimism. SJ: similarity judgements. CP: comparative pessimism. + : Women. $\widehat{O}^{\wedge}$ : Men. Y: course takers $\leq 25$ years old. O: others: course takers $>25$ years 
old. DRSS: driving-related sensation-seeking. ${ }^{a}$ over the last 12 months (in $\mathrm{km} / \mathrm{h}$ ). ${ }^{\mathrm{b}}$ within the next 12 months (in $\mathrm{km} / \mathrm{h}$ ). 
Table 5

Mean differences in self-reported speeding and DRSS ( $\mathrm{n}=539)$, by crash-risk-judgment group (comparative optimism vs similarity judgements vs comparative pessimism), sex, and age categories

\begin{tabular}{|c|c|c|c|c|c|c|c|c|c|c|c|c|}
\hline & \multicolumn{4}{|c|}{$\mathrm{CO}(\mathrm{n}=298)$} & \multicolumn{4}{|c|}{$\mathrm{SJ}(\mathrm{n}=192)$} & \multicolumn{4}{|c|}{$\mathrm{CP}(\mathrm{n}=45)$} \\
\hline & \multicolumn{2}{|c|}{ Men $(n=249)$} & \multicolumn{2}{|c|}{ Women $(n=49)$} & \multicolumn{2}{|c|}{$\operatorname{Men}(n=177)$} & \multicolumn{2}{|c|}{ Women $(\mathrm{n}=15)$} & \multicolumn{2}{|c|}{$\operatorname{Men}(n=38)$} & \multicolumn{2}{|c|}{ Women $(\mathrm{n}=7)$} \\
\hline & $\begin{array}{l}\mathrm{Y}(\mathrm{n}= \\
70)\end{array}$ & $\begin{array}{l}O \\
(n=179)\end{array}$ & $Y(n=11)$ & $O(n=38)$ & $Y(n=36)$ & $\begin{array}{l}O \\
(n=141)\end{array}$ & $\mathrm{Y}(\mathrm{n}=1)$ & $O(n=14)$ & $Y(n=11)$ & $O(n=27)$ & $\mathrm{Y}(\mathrm{n}=0)$ & $O(n=7)$ \\
\hline Measured variable & $\begin{array}{l}\text { Mean } \\
(\mathrm{SD})\end{array}$ & $\begin{array}{l}\text { Mean } \\
(\mathrm{SD})\end{array}$ & $\begin{array}{l}\text { Mean } \\
(\mathrm{SD})\end{array}$ & $\begin{array}{l}\text { Mean } \\
(\mathrm{SD})\end{array}$ & $\begin{array}{l}\text { Mean } \\
(\mathrm{SD})\end{array}$ & $\begin{array}{l}\text { Mean } \\
(\mathrm{SD})\end{array}$ & Mean & $\begin{array}{l}\text { Mean } \\
(\mathrm{SD})\end{array}$ & $\begin{array}{l}\text { Mean } \\
(\mathrm{SD})\end{array}$ & $\begin{array}{l}\text { Mean } \\
(\mathrm{SD})\end{array}$ & $\begin{array}{l}\text { Mean } \\
(\mathrm{SD})\end{array}$ & $\begin{array}{l}\text { Mean } \\
(\mathrm{SD})\end{array}$ \\
\hline DRSS & $2.7(0.8)$ & $2.2(0.7)$ & $2.6(0.5)$ & $1.9(0.6)$ & $2.8(0.8)$ & $\begin{array}{l}2.2 \\
(0.8)\end{array}$ & 4.0 & $1.9(0.7)$ & $3.0(0.5)$ & $2.1(0.7)$ & & $1.7(0.6)$ \\
\hline Preferred past speed ${ }^{a}$ & $\begin{array}{l}95.6 \\
(17.0)\end{array}$ & $\begin{array}{l}97.0 \\
(16.6)\end{array}$ & $\begin{array}{l}90.9 \\
(22.6)\end{array}$ & $\begin{array}{l}93.7 \\
(18.8)\end{array}$ & $\begin{array}{l}98.3 \\
(12.9)\end{array}$ & $\begin{array}{l}98.0 \\
(16.7)\end{array}$ & 90.0 & $\begin{array}{l}96.8 \\
(15.4)\end{array}$ & $\begin{array}{l}90.9 \\
(15.6)\end{array}$ & $\begin{array}{l}91.8 \\
(19.7)\end{array}$ & & $\begin{array}{l}98.6 \\
(12.1)\end{array}$ \\
\hline Fastest past speed & $\begin{array}{l}143.2 \\
(33.2)\end{array}$ & $\begin{array}{l}124.6 \\
(29.7)\end{array}$ & $\begin{array}{l}124.5 \\
(24.7)\end{array}$ & $\begin{array}{l}118.0 \\
(23.8)\end{array}$ & $\begin{array}{l}143.9 \\
(34.1)\end{array}$ & $\begin{array}{l}128.0 \\
(29.4)\end{array}$ & 120.0 & $\begin{array}{l}128.0 \\
(29.4)\end{array}$ & $\begin{array}{l}139.0 \\
(29.2)\end{array}$ & $\begin{array}{l}135.2 \\
(47.0)\end{array}$ & & $\begin{array}{l}126.6 \\
(19.6)\end{array}$ \\
\hline $\begin{array}{l}\text { Preferred speed at which course } \\
\text { takers intend to drive }\end{array}$ & $\begin{array}{l}90.9 \\
(13.9)\end{array}$ & $\begin{array}{l}92.2 \\
(12.3)\end{array}$ & $\begin{array}{l}89.1 \\
(17.6)\end{array}$ & $\begin{array}{l}89.3 \\
(12.3)\end{array}$ & $\begin{array}{l}95.3 \\
(10.9)\end{array}$ & $\begin{array}{l}92.3 \\
(12.2)\end{array}$ & 110.0 & $89.3(7.3)$ & $\begin{array}{l}90.4 \\
(15.6)\end{array}$ & $\begin{array}{l}88.3 \\
(13.9)\end{array}$ & & $91.4(3.7)$ \\
\hline $\begin{array}{l}\text { Fastest past speed at which course } \\
\qquad \text { b } \\
\text { takers intend to drive }\end{array}$ & $\begin{array}{l}117.8 \\
(26.5)\end{array}$ & $\begin{array}{l}111.4 \\
(23.2)\end{array}$ & $\begin{array}{l}108.2 \\
(13.3)\end{array}$ & $\begin{array}{l}106.5 \\
(18.5)\end{array}$ & $\begin{array}{l}128.3 \\
(33.3)\end{array}$ & $\begin{array}{l}111.5 \\
(24.7)\end{array}$ & 120.0 & $\begin{array}{l}106.0 \\
(20.7)\end{array}$ & $\begin{array}{l}125.4 \\
(25.4)\end{array}$ & $\begin{array}{l}111.8 \\
(23.7)\end{array}$ & & $\begin{array}{l}104.3 \\
(15.1)\end{array}$ \\
\hline
\end{tabular}


CO: comparative optimism. SJ: similarity judgements. CP: comparative pessimism. . : Women. ${ }^{\text {}}$ : Men. Y: course takers $\leq 25$ years old. O: others: course takers $>25$ years old. DRSS: driving-r 